\title{
'That was the Night I Became an Insomniac': Guilt, Trauma and Recovery in Khaled Hosseini's The Kite Runner
}

\author{
Sharfudden M \\ Research Scholar, Department of English \\ Zamorin’s Guruvayurappan College \\ Calicut, Kerala, India \\ sharfudden@gmail.com
}

Dr Rajani B

Associate Professor

Zamorin's Guruvayurappan College

Calicut, Kerala, India

DOI: https://doi.org/10.24113/ijellh.v9i4.10985

\begin{abstract}
:
'The Kite Runner' is the debut novel written by Afghan American author Khaled Hosseini. This novel is the story of Amir and Hassan, who struggles to find their space in the world because of the after-effects and fallout from a series of traumatic childhood events. The story is told by its lead character Amir who is a Pashtun belongs to the upper social class. Hassan is a Hazara who belongs to a socially backward class. Both Amir and Hassan are inseparable best friends until the day when Amir witnesses Hassan being raped by Aseef. Amir could not do anything to save Hassan and also ignores the incident and hides in silence. Rather, he drives away Hassan from
\end{abstract}


his home with a false accusation to forget his trauma. But it actually intensified his guilt and trauma. Later, political instability in Afghanistan forces Amir and his father to flee to Pakistan and later to the United States. Years later Amir gets a call from his uncle when he becomes aware that Hassan has been killed and that he was Amir's half-brother. He also learns that Hassan's son Sohrab is in Taliban's clutches. Amir takes it as a call for his redemption and sets to Taliban ruled Afghanistan to save Sohrab and bring him back to the United States. This study focuses on the role of guilt leading to psychological trauma, socio-cultural factors effecting the individual's and the collective trauma, and also analysing the recovery process of the traumatised characters. The message of this narrative is that social stratification of individuals or groups makes them an easy victim. A broader understanding of social equality can help in preventing traumatic evils thereby creating a safer society.

Keywords: Childhood Sexual Abuse, Rape, Betrayal, Guilt, Trauma, Post Traumatic Stress Disorder, Redemption

"There are two kinds of guilt: the kind that drowns you until you're useless, and the kind that fires your soul to purpose." (Sabaa Tahir, An Amber in the Ashes) Guilt can be defined as a response to the individual's action or inaction to prevent the event. It is not merely limited to the response against a deeply distressing event. Guilt reflects an individual's perception of the role played by them in a traumatic event. It is often seen as a significant phenomenon leading to post-traumatic stress disorder which results in dysfunctional behaviour among the affected individuals. Such behaviour may include the ability to foresee and prevent a traumatic event, providing insufficient justification of one's actions, violating one's integrity while doing wrong, and taking full responsibility of a traumatic event (Caruth, Unclaimed, 59). Guilt either inspires an individual to create a different end or drowns them in a 
pool of self-hate till destruction. The attitude of an individual and the surrounding circumstances often guide the path of action the traumatized individual chooses in the future.

Childhood trauma may be a result of sudden terrifying events like a natural disaster, war, violence, accident, sexual assault, death, murder, medical emergency, etc. The major reason for childhood trauma continues to be the feelings of the child about self-inability to prevent distressing incidence. In such cases, the minds of children undergo intense stress and overwhelm which becomes impossible for the child to cope up. This results in the damage to their mind paving way for psychological trauma. The victim of childhood trauma often re-experiences the memories of trauma through the repeated replay of the event in their mind, nightmares, or flashbacks of the trauma. As argued by Judith Lewis Herman in her book "Trauma And Recovery: From Domestic Abuse To Political Terror" (13), in such case the victim may choose silence as a reaction because the victim fails to express the trauma verbally. Instead, the reflection of childhood trauma can be noticed in the behavioural cues of the children. Such cues may range from altered behaviour, sleeplessness, loss of appetite, the sudden change in behaviour, change in sleeping patterns, avoidance, abnormal sexual behaviour, and hyperactivity, etc. Such behavioural changes act as a coping mechanism to avoid trauma and feel safe. The victim may also choose to respond to the painful memories of trauma by changed temperaments including fear, anger, anxiety, sadness, guilt, numbness, and avoidance, etc.

The devastating event often create psychological damage which leads to a significant self-conscious emotion of guilt among the victims (Stotz, 10). The major factors leading to guilt after a traumatic event can be an evasion of one's belief of right and wrong, perceived responsibility to prevent the event from occurring, an individual's lack of justification towards action taken during a traumatic event, and false preconceived perception of events. The shocking 
event replays in the mind of the victim with an attempt to understand what could have been done differently by the victim or witness to prevent the traumatic event. Such an understanding is followed by guilt which rises from among the memory of the event. The impact of guilt may vary based on the extent of involvement that is perceived by the trauma victim. Guilt may guide the victim to believe that their behaviour is the reason for the traumatic occurrence. As a result, the victim alters personal behaviour to avoid the memory of such guilt and trauma. It is also done as an attempt to avoid traumatic events in the future. Gradually, the altered behaviour results in changing behavioural patterns often altering the personality of the victim altogether.

Among the known factors, the role of guilt in post-traumatic stress disorder remained less explored until recent times. The burden of guilt was found to be among the most significant factors leading to post-traumatic stress disorder in the victims of childhood trauma. The victim often confirms to self-guilt and negative self-perception resulting in a disturbed state of mind. The study (D.A., 466) about the role of guilt in inflicting post-traumatic stress disorder states that both guilt and post-traumatic stress disorder occur side-by-side resulting from the traumatic event rather than as a cause or effect to one another. When the victim of childhood trauma is guided by the self-conscious emotion of guilt the symptoms are likely to be reflected in the changing postural patterns and behavioural reactions of the victim. The negative emotion of guilt contributes to the course of post-traumatic stress disorder in a later course of the victim's life. It can further influence the interpersonal and intrapersonal behaviour of the victim. Sometimes, the victim may altogether avoid the situations and people that remind them of trauma. The victim may also disconnect from relationships that bring them the memories of childhood trauma.

Trauma has a far-reaching and complex definition that remains limited to be explained in words. Explanations and words often fail to create the deserving effect that is suffered by the 
victim thereby leaving the victim crippled with emotions, to convey the actual devastating impact on the minds of the victim. Over the years, creativity has attempted to successfully explore the concept of trauma, the agents inflicting trauma, post-traumatic stress disorder, and recovery. Many authors have been highly effective in conveying the detailed insights about the mental state of the victim, the psychological struggles faced by them, and the mechanisms used by the victim to overcome trauma.

The major reason for trauma could be said to be an individual's perception of abilities in preventing an unpleasant event that was not met. Trauma and post-traumatic stress disorder are not specific to a community or culture. Rather, it can evolve in people belonging to any ethnic or cultural background. Trauma is bound by the common factor of the victim's helplessness to prevent the occurrence of the traumatic incidence. However, studies conducted on "Trauma, Post-Migration Living Difficulties, and Social Support as Predictors of Psychological Adjustment in Resettled Sudanese Refugees" (Robert Schweitzer, 187), states that particularly vulnerable groups in a community are more likely to be the target of trauma that can result in post-traumatic stress disorder. Based on the studies conducted by Dr. Marlene R. Eisen (Eisen, 263) in the field of childhood trauma and sexual abuse, it can be said that the extent of trauma caused to individuals depend upon many factors like the experience of an individual, identity of the abuser, the level of autonomy used by the abuser, and many other factors. In the majority of situations, the victim fails to grasp the trauma due to shock at the very moment it occurs but gets affected by it gradually with the realization of trauma. The traumatic incident can also return to the victim in the form of repeated flashbacks which leaves the victim haunted until the complete recovery is made. In her writings (Caruth, Trauma, 153), Cathay Caruth states that such recollection of traumatic events can lead to post-traumatic stress disorder. Often the feelings of a 
distressing event is followed by guilt which becomes a significant contributor to post-traumatic stress disorder. It is true especially among the cases where the victim undergoes regret and feels that the victim could have done something differently to prevent the traumatic event from occurring. Post-traumatic stress disorder can also evoke symptoms of distress among the victim. It could be in the form of social anxiety, low self-esteem, social distress, shame, numbness, avoidance, feeling disconnected, lack of trust, sleeplessness, nightmare, depression, and suicidal tendencies too. Guilt can also leave a significant impact on the overall wellbeing of the victim. It can influence their actions, behaviour, as well as attitude. Failure to resolve guilt can also lead to an intense impact on the mental health of the victim. This happens because the unresolved guilt restricts or complicates the emotional recovery process of the victim allowing increased psychological sufferings. Whereas when the victim focuses on resolution of the guilt the efforts are steered towards positive action ensuing recovery from trauma towards healthy emotions.

The symptoms of trauma may fade away with time. However, the triggers of trauma may likely bring back painful memories. These memories may get stuck in the nervous system of the victim leading to a psychological shock. If such a symptom does not fade away it develops into post-traumatic stress disorder becoming the constant cause of emotional and psychological pain for the victim. In some cases, the victim may try to forget the event in the long term. However, repressed memories of the occurrence may stay with the victim which can remind them of trauma. Trauma leaves a significant disruption on the minds of the victim and can lead to long term consequences as well. According to the trauma theory (Costello, 112), it is important that the victim processes the memories related to trauma; grieves over it and adapts to positive psychological functioning. Such positive coping skill enables the victims to bring together the 
memories and cues of trauma and handle them internally on their own. This also helps the victim gain self-confidence thereby enabling positive personal growth.

"I became what I am today at the age of twelve, on a frigid overcast day in the winter of 1975. I remember the precise moment, crouching behind a crumbling mud wall, peeking into the alley near the frozen creek. That was long time ago, but it's wrong what they say about the past, I've learned, about how you can bury it. Because the past claws its way out. Looking back now, I realize I have been peeking into that deserted alley for the last twenty six years." (Hosseini, Chapter 1)

The very beginning of the novel "The Kite Runner" by Khaled Hosseini lays the base for childhood trauma. The above narration draws the attention of the reader to guilt resulting from a childhood trauma caused to its character Amir. The unresolved trauma continues to haunt him for twenty-six years. Meanwhile, the behaviour and personality of Amir undergo changes that help him recover from childhood trauma. The narration of The Kite Runner is told in the first person by its main character Amir. Through the literary analysis of the narration, an effort is made to understand the role of guilt in childhood trauma.

The story is set in the backdrop of 1970s when Afghanistan replaced its constitutional monarchy with a republic. It was the time when the ruler, King Zahir Khan was away in Italy and his cousin Daoud Khan ended forty years of king's rule in Afghanistan. The Kite Runner successfully depicts social and racial conflicts in Afghanistan during those times. It is also highly effective in explaining the role of political marginalization, social strata, social deprivation, and powerlessness resulting in childhood trauma.

The story also throws light on the existing social disparity between the Pashtuns and Hazaras where the former belonged to an elite class, considered eligible for a rich and luxurious 
way of life while the latter was considered unworthy of wealth, comforts, and education. The role of Hazaras was limited to that of serving the Pashtuns. Both Assef and Amir belonged to the Pashtun community who lived the life of abundance and had the privilege to go to school and gain an education. Whereas, Hassan was a Hazara serving his master like his father Ali; deprived of the right to literacy and education. The social and economic disparity between the communities can be noted in the statements from the narration where Amir describes his house as:

"Everyone agreed that my father, my baba built the most beautiful house in the Wazir Akbar Khan District, a new and affluent neighbourhood in northern part of Kabul. Some thought it was prettiest house in all of Kabul.” (Hosseini, Chapter 2) Amir's father was well known to give extravagant parties every week where Hassan and his father will be serving the rich Pashtuns. His lavish living room even had a family picture of his grandfather with King Nadir Shah. Whereas Hassan's house was a mud shack with bare walls except for a tapestry that Amir's father had gifted them. The description of their houses itself indicates the difference in their economic and social class. While Amir belongs to a very influential class both socially and economically, Hassan comes from a poor economic and social background. This can be noted in Amir's description of Hassan's house as "On the south end of the garden, in the shadows of a loquat tree, was the servant's home, a modest little mud hut where Hassan lived with his father.” (Hosseini, Chapter 2)

The narration also throws light on the social and economic differences between the Hazaras and Pashtuns. Also, the cultural differences made Hazaras fall under the vulnerable social category. This can be noticed in the narration where Assef, the abuser of the novel states that: 
"Afghanistan is the land of Pashtuns. It always will be, always will be. We are the true Afghans, the pure Afghans, not this Flat-Nose here. His people pollute our homeland, our watan. They dirty our blood. He made a sweeping, grandiose gesture with his hands. Afghanistan for Pashtuns, I say. That's my vision.” (Hosseini, Chapter 5)

Assef has extreme feelings of hatred towards Hazaras which is very evident in the abovestated sentences. He believes that Pashtuns are the true Afghanis and that the Hazaras are impure blood polluting their homeland. He thinks that Hazaras are insignificant to Afghanistan. This holds true with most of the Pashtun community where the author has stated at many instances about Pashtuns making fun of Hassan just because he is a Hazara. He is described as flat-nosed and impure blood. The novel portrays the real social stratification of the Hazaras in Afghanistan. It has created social distance among the citizens wherein the Hazaras of Afghanistan were suppressed by Pashtuns for generations.

Aseef considers Hassan and other Hazaras as a burden to the Afghan society and also believes that he should be punished for being a Hazara in Afghanistan. Aseef plans to abuse Hassan to teach a lesson to Hassan who is a Hazara. Aseef's main intention was not only to physically abuse Hassan but also to shatter him emotionally and psychologically. Both his friends Kamal and Wali sense his sinful intention and are reluctant to follow his footprints. Aseef convinces his friends by saying that it acceptable to abuse Hassan as he is a Hazara who is born for submission to the Pashtuns. In response Kamal remains silent and looks away while Wali tells him that it is a sin as "I don't know, Wali was saying. My Father says it's sinful." (Hosseini, Chapter 7) 
Afghanistan is an Islamic nation, with strong beliefs in the valuable teachings of the Holi Quran which preaches good upbringing of children with qualities of compassion and love. According to the Holi Quran, it is considered the responsibility of parents to raise their child to be ethical and virtuous. Every child is considered valuable to society and any wrong actions against them are considered a heinous sin. The teachings say that families should protect each other from hell by raising children with high morals. The Kite Runner depicts a barbaric crime where one child is raped by another merely because they don't belong to the same lineage. During the later course of the reading of the novel, it can be found that the foundation of Aseef's thoughts lie deeper in the way he was brought up by his parents. He was made to believe that lower classes were meant to serve the upper class and that the Hazaras had no right to live a life of self-respect. Aseef's sin can be seen to be done in the light of his belief that since Hassan was a Hazara he should be inflicted to torture and injustice. However, both Wali and Kamal passively refused to inflict sexual abuse on Hassan since their parents had infused the belief that such torture is a sinful act. But they didn't stop Aseef to prevent the injustice inflicted to Hassan. This could have happened because Hassan was not a Pashtun. He was a Hazara that was a vulnerable class in Afghan society, often seen as an easy target for harassment and injustice.

The novel also throws light on ethical discrimination and wrongly interpreted teachings of the Holi Quran by Amir's teacher Mullah Fatiullah Khan. Whereas, Amir's father corrects his understanding and tells him that "but first Understand this and understand it now, Amir: You'll never learn anything of value from those bearded idiots.” (Hosseini, Chapter 3)

The thoughts and teachings of teachers like Mullah Fatiullah Khan, who was a religious extremist, paved way for grooming of children and society like Aseef who inflicted crime on the weaker section of the society. He acted as a source for trauma inflicting agent. At the same time, 
Afghanistan was also inhabited by liberal thinkers like Amir's father who rightly sensed the end of a peaceful era if ever Afghanistan was governed by the extremists. His thoughts have been stated as "They do nothing but thumb their prayer beads and recite a book written in a tongue they don't even understand. He took a sip. God help us all if Afghanistan ever falls into their hands." (Hosseini, Chapter 3)

The writer uses harsh words for extremist teachers like Mullah Fatiullah Khan and those like him and declares them "self-righteous monkeys." The propaganda of extremists like Mullah Fatiullah Khan remains focused on spreading hatred in a society or community. Often such teachings result in the inflicting heinous crimes with grave outcomes against the oppressed and the vulnerable class of the society. In the case of "The Kite Runner" such teachings lead to the creation of characters like Aseef who found pleasure and achievement while torturing people in the name of religious and social supremacy. The teachings of religious extremists induced him with the understanding that it is justifiable to commit a heinous crime against the weak and oppressed. Despite the silence of his friends Wali and Kamal, Aseef is determined to sexually harass Hassan. The teachings of extremist thinkers made it easier and justifiable for Aseef to become a sociopath. His extremist beliefs and hatred are very evident in his determined action to assault Hassan. It can also be noted in his other actions when he gifts Amir the autobiography of Adolf Hitler. This hints at Aseef's idealization and admiration of barbaric historic characters like Adolf Hitler which has resulted in heinous rape of Hassan as explained by the author Khaled Hosseini:

"It is just a Hazara, Aseef said. He turned to Kamal. But Kamal kept looking away. Fine, Aseef snapped. All I want you weaklings to do is hold him down. Can you manage that? Wali and Kamal nodded. They looked relieved. Aseef knelt 
behind Hassan, put his hands on Hassan's hips and lifted his bare buttocks. He kept one hand on Hassan's back and undid his own belt buckle with his free hand. He unzipped his jeans. Dropped his underwear. He positioned himself behind Hassan.” (Hosseini, Chapter 7)

The wrong learnings of social extremism resulted in Aseef raping a child. While it devastated Hassan, who was the direct victim of Aseef's hateful intentions, Amir who witnessed the disgraceful act of sexual abuse was also deeply affected emotionally and psychologically. Both his body and mind froze with fear, as stated in Amir's words:

"I felt my body clench up, and something cold rippled up my spine." (Hosseini, Chapter 7)

"I realized I still hadn’t breathed out. I exhaled, slowly, quietly. I felt paralyzed." (Hosseini, Chapter 7)

"I opened my mouth, almost said something. Almost. The rest of my life might have turned out differently if I had. But I didn't. I just watched. Paralyzed." (Hosseini, Chapter 7)

The unfortunate plight of Hassan shattered Amir who was left helpless by both internal and external forces to protect Hassan. Neither could he fetch help from others nor could he gain the courage to fight for Hassan. It was shattering for Amir to witness Hassan's physical abuse. The trauma of the incident made him feel helplessness resulting in shock, fear, and horror. He left the sense of control and connection due to unavailability of any action. It could be noted that the trauma strike Amir passively during the moments he caught a glimpse of Hassan's resigned face. The childhood trauma resulting from the rape of Hassan devastated Amir emotionally and psychologically. He couldn't gather the courage to prevent the trauma externally by fighting 
Aseef or gathering help from others. All he could think of doing was to run away from the psychological pain. He was helpless to handle the situation as explained by Khaled Hosseini in words:

"I STOPPED WATCHING, turned away from the alley. Something warm was running down my wrist. I blinked, saw I was still biting on my wrist, hard enough to draw blood from knuckles. I realized something else. I was weeping." (Hosseini, Chapter 7)

The novel has effectively explored the impact of childhood trauma caused to Amir when Hassan is sexually abused by Aseef while Amir witnesses the whole incident helplessly. The incident leaves him in a state of psychological trauma refuting his whole sense of safety, and security. The sudden shock was followed by numbness such that he didn't realize that he was biting his own wrist so hard that blood escaped his skin. He even took the time to realize that he was weeping.

Amir's trauma can be said to be primarily led by the feeling of guilt that resulted from abandoning Hassan who had always remained loyal to Amir and fought all the odds just for the sake of Amir. Besides being the son of his house help Ali, Hassan is also Amir's best friend. Both spend hours together playing games, talking to each other, doing pranks, and more. Since Hassan is not literate Amir reads him stories. The extent of Hassan's friendship with Amir is such that the former could do anything for Amir. This has been stated as:

"Right now, I'm going to run that blue kite for you, he said. He dropped the spool and took off running, the hem of his green chapan dragging in the snow behind him. Hassan! I called. Come back with it! He was already turning the street corner, 
his rubber boots kicking up snow. He stopped, turned. He cupped his hands around his mouth. For you a thousand times over! He said.” (Hosseini, Chapter 7)

Amir knew that Hassan had got into Aseef's clutches for the sake of winning the kite for Amir, but he couldn't gather the courage to fight Aseef and save Hassan. The memory of betrayal and inability to stand up for right doing haunts him. Like the majority of traumatized children, Amir also fails to express his trauma in words. Instead, he seeks solace in his father's embrace as:

“Then a smile played on my father's lips. He opened his arms. I put the kite down and walked into his thick hairy arms. I buried my face in the warmth of his chest and wept. Baba held me close to him, rocking me back and forth. In his arms, I forgot what I'd done. And that was good." (Hosseini, Chapter 7)

Often, support from friends and family members help victims to overcome trauma and its impact. In the case of Amir, his father's embrace pacified him for the time being, but the ghosts of trauma continued to haunt Amir in the long run. This is because Amir didn't seek external help from his father or uncle to handle the trauma. Instead, he continued fighting it within him. Unable to deal with the complexities of trauma on his own, Amir's post-traumatic stress disorder was indicated through sudden changes in his behaviour and routines. It can be noted that the post-traumatic stress disorder of Amir remained masked in him as he pretended not to have known about the incident at all. This not only distorted his healthy psychological growth but also altered his otherwise healthy friendship with Hassan who was almost inseparable before the incident. After the traumatic incident, Amir started avoiding Hassan by pretending to be busy with his studies. Amir's post-traumatic stress disorder included mental distraction, loss of 
appetite, avoidance, silence, nightmares, insomnia, headache, and suffocation. His post-traumatic stress disorder can be observed in the following lines:

"I closed my eyes, turned my face to the sun. Little shapes formed behind my eyelids' like hands playing shadow on the wall. They twisted, merged, formed a single image: Hassan's brown corduroy pants discarded on a pile of old bricks in the alley." (Hosseini, Chapter 8)

Amir's mind stayed distracted and he continued to replay the assault in his mind. The emotions in his mind were so much overworked that he could find triggers to trauma in almost everything he did. He was disturbed to the extent that nightmares did not allow him to sleep and he became insomniac. Amir's guilt overpowered his emotions in such a manner that he considered himself as a heinous monster as:

"I thought about Hassan's dream, the one about us swimming in the lake. There is no monster, he said, just water. Except he'd been wrong about that. There was a monster in the lake. It had grabbed Hassan by the ankles, dragged him to the murky bottom. I was that monster. That was the night I became insomniac." (Hosseini, Chapter 8)

Amir lost appetite which was an indication of the post-traumatic stress disorder in him. After the traumatic incident, Amir would leave his breakfast unfinished almost every day. There were changes in his day-to-day schedules. He would spend most of the time in his room reading and come out just to eat food as "I closed myself in my room. I read a book every couple of days, wrote stories, learned to draw horses." (Hosseini, Chapter 8)

Before the incident in the alley, both Amir and Hassan spent most of their time with each other but after the traumatic incident, Amir would find excuses to keep to himself and avoid 
seeing or spending time with Hassan. It has been stated by Amir in many instances as 'I'd hear Hassan shuffling around the kitchen in the morning, hear the clinking of silverware, the whistle of the teapot. I'd wait to hear the door shut and only then I would walk down to eat." (Hosseini, Chapter 8)

Amir's avoidance of Hassan can also be noted when Hassan requests Amir to accompany him and he responds as "I think I am just going to read, I said rubbing my temples." (Hosseini, Chapter 8)

Amir's avoidance of Hassan included ignoring as well as maintaining silence when he was with Hassan. He would not play with Hassan as they used to do. Amir also refused to read stories to Hassan as they did before the traumatic incidence. This can be noticed in the author's narration as:

"He asked me to read to him from the Shahnama and I told him I'd changed my mind. Told him I just wanted to go back to my room. He looked away and shrugged. We walked back down the way we'd gone up: in silence." (Hosseini, Chapter 8)

Silence and avoidance were a significant indication of post-traumatic stress disorder. Amir wanted to avoid a situation in case Hassan wanted to share the traumatic incidence with the former. He avoided Hassan because seeing Hassan bought him the pains of trauma followed by physical discomfort including headache as "Lately everytime Hassan was around, I was getting a headache." (Hosseini, Chapter 8)

Amir's feelings of immense guilt resurfaced upon facing Hassan. He was left wounded by the guilt of not being able to prevent the assault upon Hassan. His guilt is also triggered by the underlying emotion of meanness that he wanted the kite more safely than Hassan. Winning the 
kite to gain his father's attention was his priority rather than Hassan's safety and honour. This intensified his guilt further. The more he saw Hassan the more guilty he felt. The very sight of Hassan suffocated Amir and made him drench in the guilt of sin he couldn't prevent from happening. The extent of his psychological suffering can be understood by the way Amir speaks of Hassan as "Because when he was around, the oxygen seeped out of the room. My chest tightened and I couldn't draw enough air; I'd stand there gasping in my own airless bubble of atmosphere." (Hosseini, Chapter 8)

In the long term, the helplessness and the feeling of not being able to protect Hassan leave Amir in a pool of guilt. Amir remained guilt-laden for twenty-six years such that when his uncle Rahim Khan called him, the incident was still fresh to his mind as stated by the author "standing in kitchen with the receiver to my ear, I knew it wasn't just Rahim Khan on the line, it was my past of unatoned sin.” (Hosseini, Chapter 1)

Amir couldn't gather the courage to fight for Hassan when Aseef was raping him. Even after the traumatic incident, Amir chose to remain silent about it. At that moment in his childhood, Amir wanted to win his father's affection by pretending that he has won the kite. He sacrificed Hassan's dignity to get the possession of the kite because somewhere inside his deep beliefs he considered Hassan as a servant who was a Hazara and the cost he paid for the kite. Amir developed a distorted image of self because of his guilt of choosing his selfishness over the dignity of Hassan. He describes himself as:

"I ran because I was a coward. I was afraid of Aseef and what he would do to me. I was afraid of getting hurt. That's what I told myself as I turned back to the alley, to Hassan. That's what I made myself believe. I actually aspired to cowardice, because the alternative, the real reason I was running, was that Aseef was right: 
Nothing was free in this world. Maybe Hassan was the price I had to pay, the lamb I had to slay, to win Baba. Was it a fair price? The answer floated to my conscious mind before I could thwart it: He was just a Hazara, wasn't he?" (Hosseini, Chapter 7)

It can be said that Amir's inability to rise for Hassan's dignity was clubbed with his cowardness and selfishness. His guilt further intensified with Hassan's unwavering loyalty and dedication towards Amir, as has been stated by Amir when Hassan returned after the incident "Did he knew I knew? And if he knew, then what would I see if I did look in his eyes? Blame? Indignation? Or, God forbid, what I feared most: guiltless devotion? That, most of all, I couldn't bear to see.” (Hosseini, Chapter 7)

Amir wanted to talk to Hassan, but he couldn't gather the courage to. Instead, he asked Hassan to come by the pomegranate tree so that he could read him a story. But Amir couldn't pretend anymore when he saw the engravings of their friendship on the tree trunk. He felt guilty with the realization that he evaded his own beliefs of right and wrongdoings. Somewhere in his mind, he felt that he had the responsibility to protect Hassan which he failed miserably. His mind realized with pain that he had failed Hassan as a friend. This can be noted in his narration as:

"We trekked up the hill, our boots squishing in the muddy snow. Neither one of us said anything. We sat under our pomegranate tree and I knew I'd made a mistake. I shouldn't have come up the hill. The words I'd carved on the tree trunk with Ali’s kitchen knife, Amir and Hassan: The sultans of Kabul...I couldn't stand looking at them now." (Hosseini, Chapter 8)

Realizing his sin, Amir got up and threw pomegranate at Hassan provoking him to hit Amir. With this act, Amir wanted to be punished by Hassan. But Hassan's dedication and loyalty 
to Amir is such that he got hit by several pomegranates and he never hurt Amir back. Instead, in the end, he hits a pomegranate on himself to satisfy Amir's state of mind. Amir tried to get hit by Hassan as a punishment for not protecting Hassan, but Hassan refrained from punishing Amir physically as:

"I hit him with another pomegranate, in the Shoulder this time. The Juice splattered his face. Hit me back! I spat. Hit me back, god damn you! I wished he would. I wished he'd give me the punishment I craved, so maybe I'd finally sleep at night. Maybe then things could return to how they used to be between us. But Hassan did nothing as I pelted him again and again. "You're a coward! I said. Nothing but a goddamn coward! I don't know how many times I hit him. All I know is that, when I finally stopped, exhausted and panting, Hassan was smeared in red like he'd been shot by a firing squad. I fell to my knees, tired, spent, frustrated. Then Hassan did pick up a pomegranate. He walked toward me. He opened it and crushed it against his own forehead. There, he croaked, red dripping down his face like blood. Are you satisfied? Do you feel better? He turned around and started down the hill.” (Hosseini, Chapter 8)

Hassan not punishing Amir physically was the worst punishment Amir got. With Hassan's continued loyalty Amir's guilt further intensified. He was shaken when he realized that Hassan had seen Amir betray him and yet maintained his loyalty to Amir. Hassan chose silence even when he was questioned by Amir's father about the theft that Hassan never committed. Amir felt that his cowardness and inability to rise to the occasion was the reason for Hassan's rape as he realises that he was the culprit in Hassan's life. It has been stated as: 
"He knew I had betrayed him and yet he was rescuing me once again, maybe for the last time. I loved him in that moment, loved him more than I'd ever loved anyone, and I wanted to tell them all that I was the snake in the grass, the monster in the lake. I wasn't worthy of this sacrifice; I was a liar, a cheat, a thief." (Hosseini, Chapter 9)

Amir tries for redemption with his plot to send away Ali and Hassan to Hazarajat. In his deeper conscious he wants them gone so that Hassan is saved from extremists like Aseef. At the same time, he also wants to forget his trauma. To send away Hassan, Amir hides the watch that his father had gifted him along with some money at Hassan's home and frames Hassan for it. When Amir's father knows about the theft, he questions Hassan to which Hassan readily agrees as:

“THEY'D BOTH BEEN CRYING; I could tell from their red, puffed up eyes.

They stood before Baba, hand in hand, and I wondered how and when I'd become capable of causing this kind of pain. Baba came right out and asked. Did you steal that money? Did you steal Amir's watch, Hassan?" Hassan's reply was a single word, delivered in a thin, raspy voice: Yes.” (Hosseini, Chapter 9)

Amir's guilt grew further with Hassan's final sacrifice. He felt that he had been hit back and punished by Hassan's loyalty. Amir felt degraded as a human being as "THEY'D BOTH BEEN CRYING; I could tell from their red, puffed up eyes. They stood before Baba, hand in hand, and I wondered how and when I'd become capable of causing this kind of pain." (Hosseini, Chapter 9)

Amir knew well that his father trusted Hassan and if Hassan had refused of the theft, his father would have questioned him to find the truth, never to be forgiven. Hassan remained loyal 
to Amir even when he and Ali were in deep suffering caused by Amir. This is followed by Amir realising that Hassan knew Amir had seen him getting abused but did not protect him. He feels overwhelmed when he understands the grave mistake he has done; the feeling of self-guilt engulfs him with a mighty force and the guilt worsens further. The narration states Amir's realization of seeing Ali's expressions as:

"His mouth twitched, and for a moment, I thought I was a grimace. That was when I understood the depth of the pain I had caused, the blackness of the grief I had brought onto everyone, that not even Ali's paralyzed face could mask his sorrow." (Hosseini, Chapter 9)

The whole narration is a heart clenching depiction of a gradual shift from the playful days of innocence and childhood to those of Hassan and Amir being a victim to childhood trauma; a childhood bully becoming the leader of the Taliban. A significant part of the writing speaks of Amir's trauma and post-traumatic stress disorder as the narration is told in the first person. However, the author has successfully narrated the observations of the victim's trauma too. While Amir was struggling to deal with his guilt Hassan was struggling with the trauma and posttraumatic stress disorder of being a rape victim. Through Hassan's trauma, Khaled Hosseini conveys the complexity of the feelings of helplessness when tormented by childhood trauma. A feeling of powerlessness has settled permanently in Hassan. While Amir failed to express the trauma verbally, Hassan could share it with his father. Amir kept the trauma within him for years whereas Hassan shared it with his father after the initial phase of psychological shock. During the phase of shock, Hassan's post-traumatic stress disorder was characterized by avoidance, and change in sleeping patterns. He avoids facing Amir initially by not waiting to speak to Amir near 
the dining table the way he used to do before the traumatic event. This change was also noted by Amir as he observes:

"For a week I barely saw Hassan. I woke up to find toasted bread, brewed tea, and a boiled egg already on the kitchen table. My clothes for the day were ironed and folded, left on the cane-seat chair in the foyer where Hassan usually did his ironing. He used to wait for me to sit at the breakfast table before he started ironing - that way, we would talk. Used to sing too, over the hissing of the iron, sang old Hazara songs about tulip fields. Now only the folded clothes greeted me." (Hosseini, Chapter 8)

Hassan's sleeping patterns underwent a drastic change. He started spending more time sleeping. It would help him temporarily erase the memories of trauma providing short relief. Sleep is often used as a coping mechanism from trauma. It is because during sleep the world and its problems cease to exist for conscious human minds. The challenges begin again when an individual wake up from sleep. Hassan used sleep to escape from the pain induced by trauma. He attended to his chores because Ali monitored him strictly. However, Hassan embraced sleep as soon as he was done with his chores. Ali expresses the change in Hassan's sleeping habits as "Lately, it seems all he wants to do is sleep. He does his chores - I see to that - but he just wants to crawl under his blanket." (Hosseini, Chapter 8)

Apart from the change in sleeping patterns, childhood trauma had impacted Hassan to the extent that he had not been eating well and taking care of his health. As a result, Hassan became weak and lost weight. His physical weakness was observed by Amir as "Hassan looked tired too - he'd lost weight and grey circles had formed under his puffed-up eyes." (Hosseini, Chapter 6) 
However, Hassan managed to speak of the incidence to his father as a result of which Ali and Hassan decided to leave Kabul for good. Though Ali or Hassan didn't share this in the narration, Amir learns of it from Ali's protective gesture towards Hassan:

“Ali drew Hassan to him, curled his arms around his son's shoulder. It was a protective gesture and I knew whom Ali was protecting him from. Ali glanced my way and in his cold, unforgiving look, I saw that Hassan had told him. He had told him everything, about what Aseef and his friends had done to him, about the kite, about me.” (Hosseini, Chapter 9)

Life takes a different turn for Amir and his father after Ali and Hassan leave Kabul. The Soviet Union invades Afghanistan leading to arrests, bombings, and atrocities on Afghan citizens. Situations become tough with the arrival of Russian soldiers who are seen patrolling the streets revoking the freedom of Afghans as:

"no grim faced Russian soldiers patrolling the sidewalks, no tanks rolling up and down the street [with] turrets swivelling like accusing fingers, no rubble, no curfews, no Russian Army Personnel Carriers weaving through the bazaars." (Hosseini, Chapter 10)

The political situations worsen due to which both Amir and his father are forced to escape from Kabul and seek refuge in Pakistan. The continued political unrest in Afghanistan makes them move to the United States permanently.

Though Amir tries to forget the trauma and lead a normal life. by attending college, gets marries, and becomes a successful author; the trauma remains with him until the day he gets a call from his father's friend Rahim Khan. It was a call for redemption - the redemption from his past sins done to Hassan. He also learns from Rahim Khan that Hassan was his half-brother. 
Determined to correct his past mistakes, Amir decides to save Hassan's son, Sohrab. He returns to Taliban ruled Afghanistan to seek Sohrab where he finds the child in captivity of Aseef who had become a prominent Taliban leader.

Amir's actions to recovery were highly difficult for him as he had to face the ghosts from the past. When Amir offered money to Aseef to take away Sohrab with him, Aseef refused and he told that he was on a mission to wipe out non-natives from Afghanistan. Though Amir feared Aseef's intentions, he gathered up the courage to argue with Aseef as:

"What mission is that? I heard myself say. Stoning adulterers? Raping children? Flogging women for wearing high heels? Massacring Hazaras? All in the name of Islam? The words spilled suddenly and unexpectedly, came out before I could yank up the leash. I wish I could take them back. Swallow them. But they were out. I had crossed a line.” (Hosseini, Chapter 22)

Amir's trauma had haunted him for years such that when he decides to fight for Sohrab, notable positive changes come to limelight for Amir. As a child, Amir thought of Hazaras as downtrodden class resulting from which he didn't take efforts to save Hassan from the sexual assault. His disregard for the socially downtrodden class is also noted when he mocks Hassan for his ignorance at various instances in the narration. Amir's character also lacked the courage to fight for the right. He feared Aseef such that he never even confronted Aseef for the wrongdoings to his friend Hassan. Moving to America and pursuing studies helped Amir undergo positive changes where he was not insecure and vouched for equality of every human being. Amir's quest to redemption not only lead him back to Taliban ruled Afghanistan but he also confronted and challenged Aseef to gain the freedom for Sohrab. Amir gained the confidence and courage to fight against the wrong. His redemption began with his attempt to 
fight for what was believed was ethical. It was something he had failed to do for Hassan. This intimidated Aseef and he agreed to free Sohrab on a condition. The condition was to fight with him and win. The thought of winning from Aseef was far from reality for Amir as he had never fought with anyone throughout his life. But he decided to do it for Hassan and Sohrab. During the fight, Amir's jaws were shattered, ribs snapped, left cheekbone snapped, and teeth were broken. In between the immense pain, Amir starts laughing suddenly that leaves Aseef perplexed. Amir laughs through his pains for the first time after the incident in the alley as "I don't know at what point I started laughing, but I did. It hurt to laugh, hurt my jaws, my ribs, my throat. But I was laughing and laughing." (Hosseini, Chapter 22)

It can be said that the series of actions towards recovery had led him to redemption and healing. Sometimes the trauma might have caused years back, but the recovery happens at a way later period of life. Sohrab's situation demanded action from Amir, who was also the victim of trauma that had caused twenty-six years back. Amir was able to wash away his guilt by gathering the guts to fight the powerful Aseef and protect Sohrab from the clutches of the Taliban. He had felt relieved in the intense physical pain because he knew he had not sinned. Amir has stood up for his faiths, beliefs, and ethics as “My body was broken - just how badly I wouldn't find out until later - but I felt healed. Healed at last. I laughed. Then the end. That, I'll take to my grave." (Hosseini, Chapter 22)

After Amir rescues Sohrab from Taliban and returns to the United States, he and Soraya adopt Sohrab to give him a good life. Amir's changed mentality can be witnessed in his response to his father-in-law who raises concern over adopting Sohrab because he is a Hazara. Amir is quick to put a stop to the limited thoughts of his father-in-law. Guided by his beliefs and ethics, 
Amir warns him as "You will never again refer to him as Hazara boy in my presence. He has a name and it's Sohrab.” (Hosseini, Chapter 25)

It can be said that the recovery to a trauma begins the moment the victim accepts the situation. In Amir's case, he can be said to have recovered and healed from his childhood trauma not just by saving Sohrab and giving him good life but also through the narration by which he accepted his flaws and limitations without the fear of being judged.

Sohrab's trauma forms a significant part of the later narration. He is the son of Hassan and Farzana, who were killed by the Taliban. After his parents' death, Sohrab was sent to an orphanage from where he was picked up by a Taliban official Aseef. There Sohrab is made to dress like girls and is also sexually abused by Aseef:

"His head was shaved, his eyes darkened with mascara, and his cheeks glowed with an unnatural red. When he stopped in the middle of the room, the bells strapped around his anklets stopped jingling." (Hosseini, Chapter 3)

"Sohrab danced in a circle. Eyes closed, danced until the music stopped. The bells jingled one final time when he stomped his foot with the song's last note. He froze in midspin. Bia bia my boy, the Talib said calling Sohrab to him, head down, stood between his thighs. The Talib wrapped his arms around the boy. How talented he is, nay, my Hazara boy! He said. His hands slid down the child's back, then up, felt under his armpits. One of the guards elbowed other and snickered." (Hosseini, Chapter 22)

It could be said that Sohrab's post-traumatic stress disorder depicted helplessness and hopelessness followed by fear to the extent that he avoided any eye contact with the people as 
"His eyes fell on me. Lingered. Then he looked away. Looked down at his naked feet." (Hosseini, Chapter 22)

Both Sohrab and Amir manage to escape Aseef and Amir promises Sohrab that he will be adopted by the former and will never have to go to the orphanage again. However, the adoption process is hindered due to legal aspects wherein the death certificate of Sohrab's parents is not available as "So the INS won't grant a visa unless it's clear the child meets the definition of an eligible orphan. I'm sorry, I know it sounds ridiculous but you need death certificates." (Hosseini, Chapter 24)

Sohrab is left with the only option of returning to the orphanage. His past experiences haunt him, and he is terrorized by the news of going back to orphanage again, as:

"Please! Please, no! He croaked. I'm scared of that place. They'll hurt me! I don't want to go. No one is going to hurt you. Not ever again. Yes they will! They always say they won't but they lie. They lie! Please, God! I wiped the tears streaking down his cheek with my thumb. Sour apples, remember? It's just like the sour apples, I said softly. No it's not. Not that place. God, oh God. Please, no!" He was trembling, snot and tears mixing on his face." (Hosseini, Chapter 24)

The trauma caused by the Taliban has left a deep scar on the mind of Sohrab such that he decides to give up his life instead of going back to the orphanage. He almost kills himself by slitting his veins using an old blade. However, he is saved by the Doctors and survives the attempt. Amir soon finds a way to adopt Sohrab and gives him a new home in California. Though he is safe with Amir, Sohrab still reflects post-traumatic stress disorder in his silence and numbness as "The unanswered questions, the blank stares, the silence, it was all too painful." (Hosseini, Chapter 25) 
Sohrab feels that his world has been destroyed and would never be the same again. He thinks that his home, people, and country are taken over by terror which will never remain the same as it used to be. During the celebration of Afghan New Year Amir offers a kite to Sohrab for him to fly. Sohrab remains aloof for some time but shatters his limitations to fly the kite along with Amir. He enjoys flying kite with Amir and cuts another kite. A smile escapes Sohrab's lips and Amir asks him if he wants Amir to run that kite for him. Though Sohrab did not respond Amir can read his expressions and says, "For you a thousand times over." (Hosseini, Chapter 25)

Amir runs to fetch the kite as Hassan once did for him. Amir attempts to reciprocate the love to Sohrab, that Hassan once gave him. He runs for redemption from the psychological trauma. This act doesn't promise to bring any drastic changes in Sohrab but it seems to be a beginning of the healing process for Sohrab's trauma.

Through his novel "The Kite Runner”, Khaled Hosseini has provided detailed insights into the state of mind of a child who is a victim to childhood psychological trauma. The narration helps the reader understand the psychological pain caused to a victim of childhood trauma resulting from witnessing his friend getting raped. The novel is also highly effective in depicting the trauma inflicting agents, post-traumatic stress disorder, and the recovery of the victim from childhood psychological trauma. 


\section{Works Cited}

Bloom, H. Bloom's guides:Khaled Hosseini's The Kite Runner. 2009.

Caruth, Cathy. The Unclaimed Experience : Trauma, Narrative and History. Baltimore : John Hopkins University Press, 1996.

—. Trauma: Exploration in memory. Baltimore : John Hopkins University Press, 1995.

Freud, Sigmund. Beyond the pleasure principle. 1990.

Herman, Judith Lewis. Trauma and Recovery. Basic Books, 1992.

Hosseini, Khaled. The Kite Runner. Riverhead Books, 2003.

Terr, L. Too scared to cry:Psychic trauma in childhood. Harper \& Row. 1990.

Van Derr Kolk, Bessel. The Body Keeps the Score. 2003.

Whitehead, Ann. Trauma fiction. Edinburgh University Press, 2004. 